\title{
Metabolism of parenterally administered fat emulsions in the rat: studies of fatty acid oxidation with $1-{ }^{13} \mathrm{C}$ - and $8-{ }^{13} \mathrm{C}$-labelled triolein
}

\author{
Wolfgang Bäurle ${ }^{1}$, Herbert Brösicke ${ }^{2}$, Dwight E. Matthews ${ }^{3}$, Karin Pogan ${ }^{1}$ and Peter Fürst ${ }^{1 *}$ \\ ${ }^{1}$ Institute for Biological Chemistry and Nutrition, University of Hohenheim, Garbenstrasse 30, 70593 Stuttgart, Germany \\ ${ }^{2}$ GCMS-Laboratory, Children's Hospital of the Free University of Berlin, Heubnerweg 16, 14059 Berlin, Germany \\ ${ }^{3}$ Department of Medicine, The University of Vermont College of Medicine, Given Building B217, Endo, Burlington, \\ VT 05405, USA
}

(Received 26 June 1997-Revised 16 October 1997-Accepted 5 November 1997)

\begin{abstract}
To reassess the hypothesis that fatty acid catabolism occurs to completion via $\beta$-oxidation, male Sprague-Dawley rats receiving continuous total parenteral nutrition (TPN) including $43 \%$ energy as fat were infused with $\left[1-{ }^{13} \mathrm{C}\right]$ - or $\left[8^{-13} \mathrm{C}\right]$ triolein. Expired $\mathrm{CO}_{2}$ was collected continuously for $4 \mathrm{~h}$ and its ${ }^{13} \mathrm{C}:{ }^{12} \mathrm{C}$ ratio determined by isotope-ratio mass spectrometry. Bicarbonate retention was also assessed over $4 \mathrm{~h}$ by infusion of $\mathrm{NaH}^{14} \mathrm{CO}_{3}$ and measurement of the expired ${ }^{14} \mathrm{CO}_{2}$. A possible loss of label from $\left[8{ }^{13} \mathrm{C}\right]$ oleic acid from the citric acid cycle via labelled acetyl-CoA without oxidation to $\mathrm{CO}_{2}$ was assessed by infusing further animals with acetate labelled with ${ }^{14} \mathrm{C}$ either at $\mathrm{C}$ atoms 1 or 2 and determination of its conversion to expired ${ }^{14} \mathrm{CO}_{2}$. At isotopic steady state, 63.2 (SE 1.6$) \%(n 8)$ of the infused $\left[1-{ }^{14} \mathrm{C}\right.$ ]acetate and 46.0 (SE $1.2) \%(n 8)$ of $\left[2-{ }^{14} \mathrm{C}\right]$ acetate was recovered as expired ${ }^{14} \mathrm{CO}_{2}$. After correction for bicarbonate retention and non-oxidative isotope loss, 37.3 (SE 1.2)\% (n 20) of the $\left[1-{ }^{13} \mathrm{C}\right]$ triolein was found to have been oxidized, whereas 32.6 (SE 1.0$) \%\left(n\right.$ 20) of the $\left[8^{13} \mathrm{C}\right]$ triolein was oxidized $(P \leq 0.01)$. The lower oxidation of the $\mathrm{C}$ atom at position 8 of oleic acid than that at position 1 indicates incomplete oxidative breakdown of the fatty acid after entering $\beta$-oxidation.
\end{abstract}

\author{
${ }^{13}$ C-labelled triolein: $\beta$-Oxidation: Total parenteral nutrition
}

Parenteral fat is an integral part of nutritional support, providing essential fatty acids and high amounts of energy in a low volume of fluid (Silberman, 1986). Generally, it is assumed that the portion of the infused fat that is not stored will be completely degraded by mitochondrial $\beta$-oxidation to $\mathrm{CO}_{2}$ and water, thereby producing heat and ATP. The nature and efficacy of $\beta$-oxidation have generally been assessed by employing ${ }^{14} \mathrm{C}$-labelled triacylglycerols (Geyer et al. 1948; Lerner et al. 1949; Eckart et al. 1973; Nordenström et al. 1982; Chen, 1984; Bender et al. 1985; Johnson et al. 1990), or in more recent studies, by means of ${ }^{13}$ C-labelled triolein (Paust et al. 1984, 1989; Brösicke et al. 1985; Park et al. 1986; Adolph et al. 1989) or trioctanoin (Watkins et al. 1977; Wolfram \& Metges, 1988; Sulkers et al. 1989). In human beings, the degree of oxidation of long-chain triacylglycerols and medium-chain triacylglycerols varies between 11 and $30 \%$ and 31 and $52 \%$ respectively (Weinman et al. 1950, 1951; Eckart et al.
1973; Watkins et al. 1977; Allsop et al. 1978; Nordenström et al. 1982; Wolfram \& Metges, 1988; Paust et al. 1989; Sulkers et al. 1989; Thompson et al. 1989). In rats, however, the extent of oxidation is markedly higher: $36-67 \%$ for long-chain triacylglycerols and $70-90 \%$ for mediumchain triacylglycerols (Geyer et al. 1948; Lerner et al. 1949; Chen, 1984; Paust et al. 1984; Bender et al. 1985; Brösicke et al. 1985; Park et al. 1986; Adolph et al. 1989; Johnson et al. 1990).

Most studies of fatty acid catabolism using isotopes are performed with fatty acids labelled at the first $\mathrm{C}$ atom (carboxyl-C), i.e. there is a tacit assumption that $\beta$ oxidation of fatty acids goes to completion so that the release of the first $\mathrm{C}$ atom as $\mathrm{CO}_{2}$ indicates oxidation of all of the $\mathrm{C}$ atoms (Weinman et al. 1950). The validity of this assumption has never been definitely proven. Early work with tripalmitin ${ }^{14} \mathrm{C}$-labelled in positions 1,6 or 11 supported the hypothesis of complete $\beta$-oxidation (Wein-

Abbreviations: TPN, total parenteral nutrition; $V_{\mathrm{CO}_{2}}$, total $\mathrm{CO}_{2}$ production

*Corresponding author: Prof. Peter Fürst, fax +49 711 4592283, email b-c-nutr@uni-hohenheim.de 
man et al. 1950). However, results of a subsequent study with tristearin ${ }^{14} \mathrm{C}$-labelled in positions 1 or 6 did not confirm this hypothesis (Weinman et al. 1951).

In the present study we administered $1-{ }^{13} \mathrm{C}$ - and $8-{ }^{13} \mathrm{C}$ labelled triolein to rats during total parenteral nutrition (TPN). One hypothesis is that fatty acids labelled on an even-numbered $\mathrm{C}$ atom yield acetyl-CoA labelled in $\mathrm{C} 2$, which may partly be shunted to fates other than oxidation to $\mathrm{CO}_{2}$ in the citric acid cycle. To test this, we infused, separately, $\left[1-{ }^{14} \mathrm{C}\right]-$ and $\left[2-{ }^{14} \mathrm{C}\right]$ acetate (i.e. the direct precursors of acetyl-CoA) so that any difference in the recoveries of the differently labelled acetate molecules as expired ${ }^{14} \mathrm{CO}_{2}$ would indicate diversion of the second $\mathrm{C}$ atom in acetyl-CoA derived from $\left[8-{ }^{13} \mathrm{C}\right]$ triolein, e.g. to gluconeogenesis or other fates.

\section{Materials and methods}

\section{Animals and total parenteral nutrition}

Male Sprague-Dawley rats, weighing 220-240 g, were adapted for $5 \mathrm{~d}$ in metabolic cages in a light- and temperature-controlled room. They consumed ad libitum a commercial standard rat chow (Altromin ${ }^{\mathbb{R}}$, Altromin, Lage, Germany) and tap water.

A central catheter was inserted into the external jugular vein and placed in the right side of the heart after the animals were anaesthetized by an intraperitoneal injection of Inoketam ${ }^{\mathbf{R}} 100 \mathrm{ml} / 1$ (Virbac $\mathrm{GmbH}$, Bad Oldesloe, Germany) and Rompun ${ }^{\mathrm{B}} 20 \mathrm{ml} / 1$ (Bayer, Leverkusen, Germany). The end of the catheter was passed subcutaneously to be exteriorized in the dorsal midscapular region by means of a trocar. It was protected by a metal harness, thus allowing continuous parenteral nutrition through the catheter while enabling the animals to move about freely.

After a $3 \mathrm{~d}$ recovery period on oral feeding, the animals received continuous TPN with $(\mathrm{g} / \mathrm{kg}$ per $\mathrm{d}): \mathrm{N}$ (Traumasteril $10 \%{ }^{\mathbb{B}}$ ) 2, glucose (Glucosteril $50 \%{ }^{\mathfrak{R}}$ ) 30 , and fat (Lipovenös $20 \%{ }^{\mathbb{R}}$ ) 12. All solutions were provided by Fresenius AG (Bad Homburg, Germany). The TPN solution was supplemented with vitamins (Multibionta ${ }^{B}$, E. Merck, Darmstadt, Germany) and trace elements (Tracitrans ${ }^{\circledR}$, Fresenius $A G$ ) and was infused by means of a syringe pump (Fresenius AG) at a rate of $2.60 \mathrm{ml} / \mathrm{h}$. Total energy supply was $1175 \mathrm{~kJ} / \mathrm{kg}$ per $\mathrm{d}$.

\section{Carbon dioxide trapping system}

After $24 \mathrm{~h}$ on TPN, the animals were placed in a gas-tight metabolic cage of approximately 2.5 litres. A current of $\mathrm{CO}_{2}$-free air was drawn through the cage at a rate of 15 (SE 1) litres/h. Expired $\mathrm{CO}_{2}$ was collected by aspiration for consecutive periods of $10 \mathrm{~min}$ through $\mathrm{CO}_{2}$-traps arranged in two parallel series, each containing $10 \mathrm{ml} 1 \mathrm{M}-\mathrm{NaOH}$ allowing $\mathrm{CO}_{2}$ to be absorbed quantitatively as carbonate. A constant light vacuum of $7-10 \mathrm{mmHg}$ prevented loss of expired $\mathrm{CO}_{2}$ from the system.

\section{Bicarbonate retention}

A portion of the labelled $\mathrm{CO}_{2}$ produced during the oxidation of a C-labelled substrate is retained in the body; the extent of this bicarbonate retention was determined as recommended by Thompson et al. (1989). Briefly, the animals were infused with $\mathrm{NaH}^{14} \mathrm{CO}_{3}(200 \mu \mathrm{l} / \mathrm{kg}$ per $\mathrm{h}$ of a $1.2 \mathrm{mM}$ solution; specific activity: $307 \mathrm{Mbq} / \mathrm{mmol}$; Sigma, St. Louis, MO, USA) during ongoing TPN over $4 \mathrm{~h}$, and the expired $\mathrm{CO}_{2}$ was trapped at $10 \mathrm{~min}$ intervals. Duplicate $1 \mathrm{ml}$ portions of these samples were added to $4 \mathrm{ml}$ liquid scintillation cocktail (Rotiszint ${ }^{\overline{\mathrm{B}}}$ eco plus, Roth, Karlsruhe, Germany), and the radioactivity was quantified in a liquid scintillation counter (Beckman LS 1801, Beckman, Irvine, CA, USA).

At isotopic steady state, the percentage of the infused $\left[{ }^{14} \mathrm{C}\right]$ bicarbonate retained was calculated by dividing the rate of ${ }^{14} \mathrm{CO}_{2}$ excretion (disintegrations/min per min) by the rate of radioactivity infusion.

\section{$\left[^{13}\right.$ C]oleic acid oxidation}

At $48 \mathrm{~h}$ after the start of TPN, rats in two equal groups ( $n$ 20) randomly received a combined bolus of $\mathrm{NaH}^{13} \mathrm{CO}_{3}$ $(0.06-0.42 \mu \mathrm{mol} / \mathrm{kg})$ and $\left[1-{ }^{13} \mathrm{C}\right]-$ or $\left[8-{ }^{13} \mathrm{C}\right]$ triolein $(2-20$ $\mu \mathrm{mol} / \mathrm{kg}$ ) and immediately afterwards, a constant infusion of a tracer amount of either $\left[1-{ }^{13} \mathrm{C}\right]-$ or $\left[8-{ }^{13} \mathrm{C}\right]$ triolein $(16-$ $24 \mu \mathrm{mol} / \mathrm{kg}$ per $\mathrm{h}$ ) over $4 \mathrm{~h}$. Tracer priming of the bicarbonate pool decreases the time until attainment of a new steady state of the ${ }^{13} \mathrm{C}$-enrichment in expired $\mathrm{CO}_{2}$ (Allsop et al. 1978). $\left[{ }^{13} \mathrm{C}\right]$ bicarbonate and ${ }^{13} \mathrm{C}$-labelled triolein emulsions were provided by Fresenius AG.

Between 60 and $30 \mathrm{~min}$ before and throughout each ${ }^{13} \mathrm{C}$ infusion experiment, expired $\mathrm{CO}_{2}$ was collected by absorbing it into $\mathrm{NaOH}$ for consecutive periods of $10 \mathrm{~min}$. The total $\mathrm{CO}_{2}$ production $\left(V_{\mathrm{CO}_{2}}\right)$ was determined titrimetrically from the amount of $\mathrm{CO}_{2}$ trapped during each sampling period.

\section{Isotope-ratio mass spectrometry}

Duplicate portions of each trapped $\mathrm{CO}_{2}$ sample were injected into evacuated $20 \mathrm{ml}$ Vacutainers ${ }^{\mathbb{\mathrm { B }}}$ (Becton Dickinson, Heidelberg, Germany), and the $\mathrm{CO}_{2}$ released by injection of $1 \mathrm{ml} 15 \mathrm{M}-\mathrm{H}_{3} \mathrm{PO}_{4}$. The ${ }^{13} \mathrm{C}$-enrichment of each $\mathrm{CO}_{2}$ sample was determined by means of a Finnigan MAT 251 Delta E dual-inlet multi-collector isotope-ratio mass spectrometer. The operation and performance of this automated system have been described in detail by Scrimgeour \& Rennie (1988).

The percentage recovery of the infused label was calculated from the expired ${ }^{13} \mathrm{CO}_{2}$ according to a modification of the formula given by Schoeller et al. (1980):

$$
\% \text { recovery of infused label }=\frac{\mathrm{E} \times V_{\mathrm{CO}_{2}}}{\mathrm{~F}_{\mathrm{I}} \times \mathrm{P} \times n \times{ }^{14} \mathrm{CO}_{2 \exp }},
$$

where $\mathrm{E}$ is the mean ${ }^{13} \mathrm{C}$ enrichment in the $\mathrm{CO}_{2}$ samples taken at isotopic steady state in atom \% excess. The enrichment is the difference between the mean ${ }^{13} \mathrm{C}$ content 
in the breath $\mathrm{CO}_{2}$ samples taken before isotope infusion (baseline ${ }^{13} \mathrm{C}$ expiration) and the samples taken at isotopic steady state in atom $\%{ }^{13} \mathrm{C} ; V_{\mathrm{CO}_{2}}$ is the $\mathrm{CO}_{2}$ production during isotopic steady state $(\mathrm{mmol} / \mathrm{kg}$ per $\mathrm{h}) ; \mathrm{F}_{\mathrm{l}}$ is the infusion rate of $\left[{ }^{13} \mathrm{C}\right]$ triolein $(\mu \mathrm{mol} / \mathrm{kg}$ per $\mathrm{h}) ; \mathrm{P}$ is the isotopic purity of $\left[{ }^{13} \mathrm{C}\right]$ triolein $(=99 \%) ; n$ is the number of ${ }^{13} \mathrm{C}$ atoms per $\left[{ }^{13} \mathrm{C}\right]$ triolein molecule $(=3) ;{ }^{14} \mathrm{CO}_{2} \exp$ is the recovery of infused $\mathrm{H}^{14} \mathrm{CO}_{3}$ as breath ${ }^{14} \mathrm{CO}_{2}$.

\section{${ }^{14}$ C-labelled acetate infusion}

In a separate experiment, sixteen rats in two equal groups randomly received a constant infusion of either $\left[1-{ }^{14} \mathrm{C}\right]$ - or $\left[2-{ }^{14} \mathrm{C}\right.$ ]acetate $(8.7 \mu \mathrm{l} / \mathrm{kg}$ per $\mathrm{h}$ of a $3.8 \mathrm{mM}$ aqueous solution; specific activity: 1961 and $2079 \mathrm{Mbq} / \mathrm{mmol}$ respectively; Amersham Buchler $\mathrm{GmbH}$, Braunschweig, Germany) over $4 \mathrm{~h}$ admixed to the TPN solution. At isotopic steady state, the rate of ${ }^{14} \mathrm{CO}_{2}$ exhalation (\% recovery) was determined for both groups as described earlier.

The ratio of the recoveries of the differently labelled acetate molecules as expired ${ }^{14} \mathrm{CO}_{2}$ was used to correct the possible loss of label derived from $\left[8-{ }^{13} \mathrm{C}\right]$ triolein:

$\%$ oxidation of $\left[8-{ }^{13} \mathrm{C}\right]$ triolein $=\%$ recovery of infused label

$$
\times \frac{\text { recovery of }\left[1-{ }^{14} \mathrm{C}\right] \text { acetate as breath }{ }^{14} \mathrm{CO}_{2}}{\text { recovery of }\left[2-{ }^{14} \mathrm{C}\right] \text { acetate as breath }{ }^{14} \mathrm{CO}_{2}} \text {. }
$$

\section{Definition of steady state}

We operationally define a quasi-steady state by considering the end period of each infusion experiment to be $45 \mathrm{~min}$. All data sets of this period were averaged for calculation.

\section{Statistical analyses}

Differences between groups were tested for significance by performing a Wilcoxon two-sample test, using the software package Statistical Analysis System SAS ${ }^{\circledR}$ (Statistical Analysis Systems, 1988) running on an IBM personal computer. The results are expressed as means with their standard errors.

\section{Results}

The mean recovery of infused $\left[{ }^{14} \mathrm{C}\right]$ bicarbonate as ${ }^{14} \mathrm{CO}_{2}$ at isotopic steady state was 90.5 (SE 1.0)\% (Fig. 1). The interindividual variation was between 82 and $100 \%$ ( $n$ 23).

During infusion of $\left[1-{ }^{14} \mathrm{C}\right]-$ and $\left[2-{ }^{14} \mathrm{C}\right]$ acetate, isotopic steady state of ${ }^{14} \mathrm{CO}_{2}$ was attempted at 63.2 (SE 1.6)\% (n 8) of the infused $\left[1-{ }^{14} \mathrm{C}\right.$ ]acetate radioactivity and at $46.0(\mathrm{SE}$ $1.2) \%$ of the infused $\left[2-{ }^{14} \mathrm{C}\right]$ acetate radioactivity $\left(\begin{array}{ll}n & 8\end{array}\right)$ (Figs. 2 and 3).

At isotopic steady state, mean recovery of $\left[8-{ }^{13} \mathrm{C}\right]$ triolein was 23.8 (SE 0.7$) \%(n 20)$ whereas that of $\left[1-{ }^{13} \mathrm{C}\right]$ triolein was 37.3 (SE 1.2)\% (n 20) (Fig. 4). The difference was significant $(P \leq 0 \cdot 001)$.

The recovery of infused $\left[1-{ }^{13} \mathrm{C}\right]$ triolein as expired ${ }^{13} \mathrm{CO}_{2}$ was corrected for bicarbonate retention to determine the

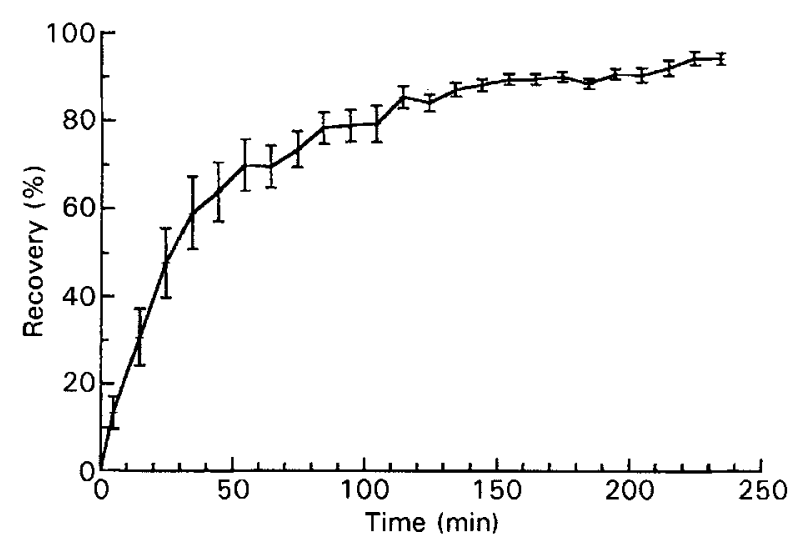

Fig. 1. Percentage recovery of ${ }^{14} \mathrm{C}$ as ${ }^{14} \mathrm{CO}_{2}$ in expired air from rats infused with $\mathrm{NaH}^{14} \mathrm{CO}_{3}$. The expired ${ }^{14} \mathrm{CO}_{2}$ was trapped over successive periods of $10 \mathrm{~min}$ and quantified in a liquid scintillation counter. Values are means for 23 rats, with standard deviations represented by vertical bars.

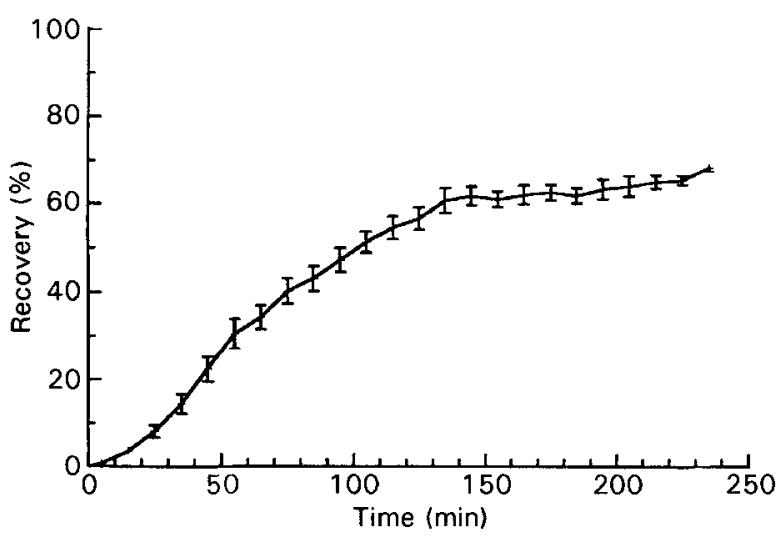

Fig. 2. Percentage recovery of ${ }^{14} \mathrm{C}$ as ${ }^{14} \mathrm{CO}_{2}$ in expired air from rats infused with $\left[1-{ }^{14} \mathrm{C}\right]$ acetate. The expired ${ }^{14} \mathrm{CO}_{2}$ was trapped over successive periods of $10 \mathrm{~min}$ and quantified in a liquid scintillation counter. Values are means for eight rats, with standard deviations represented by vertical bars.

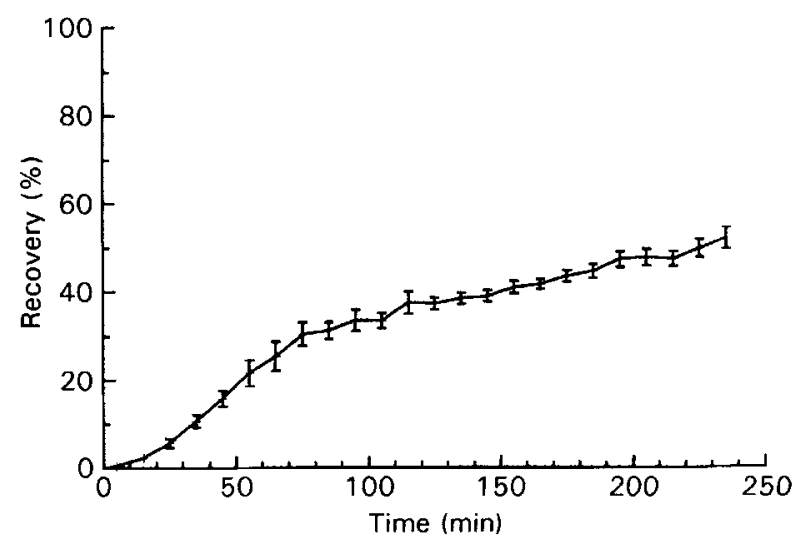

Fig. 3. Percentage recovery of ${ }^{14} \mathrm{C}$ as ${ }^{14} \mathrm{CO}_{2}$ in expired air from rats infused with $\left[2-{ }^{4} \mathrm{C}\right]$ acetate. The expired ${ }^{14} \mathrm{CO}_{2}$ was trapped over successive periods of $10 \mathrm{~min}$ and quantified in a liquid scintillation counter. Values are means for eight rats, with standard deviations represented by vertical bars. 




Fig. 4. Example of the pattern of exhalation of ${ }^{13} \mathrm{CO}_{2}$ by rats during the infusion of $\left\{1{ }^{13} \mathrm{C}\right\}$ triolein $\left(-\mathbf{v}^{-}\right)$or $\left[8{ }^{-13} \mathrm{C}\right\}$ triolein $(-7)$. After priming with $\left[{ }^{13} \mathrm{C}\right]$ bicarbonate and the respective labelled emulsion, the enrichment of the exhaled $\mathrm{CO}_{2}$ with ${ }^{13} \mathrm{C}$ rose exponentially. After about $180 \mathrm{~min}$, a new steady-state enrichment was attained. The difference between baseline ${ }^{13} \mathrm{C}$-enrichment of the exhaled $\mathrm{CO}_{2}$ and steady-state enrichment during ${ }^{13} \mathrm{C}$ infusion was used to calculate the percentage recovery of the infused label.

size of the oxidized fraction. To quantify the oxidized fraction of $\left[8-{ }^{13} \mathrm{C}\right]$ triolein, it is necessary to consider not only bicarbonate retention, but also the isotope loss from the second $\mathrm{C}$ atom in acetyl-CoA. Thus, the percentage oxidation of $\left[8-{ }^{13} \mathrm{C}\right]$ triolein was calculated by multiplying the percentage recovery by the ratio mean recovery of $\left[1-{ }^{14} \mathrm{C}\right]-:\left[2-{ }^{14} \mathrm{C}\right]$ acetate as breath ${ }^{14} \mathrm{CO}_{2}(=1 \cdot 37$, see pp. 382-383). The resulting value, 32.6 (SE 1.0 )\%, was still $13 \%$ lower $(P \leq 0.01)$ than the equivalent value for oxidation of $\left[1-{ }^{13}\right.$ C $]$ triolein, 37.3 (SE 1.2 )\% (Table 1).

Table 1. Fractional oxidation of infused $\left[1-{ }^{13} \mathrm{C}\right]$ - and $\left[8-{ }^{13} \mathrm{C}\right]$ triolein during isotope steady state ( $\%$ of infused dose) in rats

(Values are corrected for bicarbonate retention and non-oxidative isotope loss)

\begin{tabular}{|c|c|c|c|}
\hline $\begin{array}{l}\text { Animal } \\
\text { no. }\end{array}$ & $\begin{array}{c}\text { Fractional oxidation } \\
\text { of }\left[1-{ }^{13} \mathrm{C}\right] \text { triolein }\end{array}$ & $\begin{array}{c}\text { Animal } \\
\text { no. }\end{array}$ & $\begin{array}{c}\text { Fractional oxidation } \\
\text { of }\left[8-{ }^{13} \mathrm{C}\right] \text { triolein }\end{array}$ \\
\hline 1 & 34.7 & 21 & 28.6 \\
\hline 2 & 38.1 & 22 & 29.9 \\
\hline 3 & 39.8 & 23 & 34.8 \\
\hline 4 & 42.8 & 24 & 41.0 \\
\hline 5 & 37.9 & 25 & 26.0 \\
\hline 6 & 42.4 & 26 & 38.3 \\
\hline 7 & 36.8 & 27 & 32.5 \\
\hline 8 & $31 \cdot 1$ & 28 & 33.9 \\
\hline 9 & 34.0 & 29 & 39.2 \\
\hline 10 & 39.5 & 30 & $32 \cdot 2$ \\
\hline 11 & 38.9 & 31 & 32.5 \\
\hline 12 & 34.3 & 32 & 32.4 \\
\hline 13 & 40.5 & 33 & 28.7 \\
\hline 14 & $53 \cdot 6$ & 34 & 35.8 \\
\hline 15 & 28.6 & 35 & 22.8 \\
\hline 16 & 33.0 & 36 & 340 \\
\hline 17 & $39 \cdot 3$ & 37 & 36.2 \\
\hline 18 & 33.1 & 38 & 32.9 \\
\hline 19 & 34.0 & 39 & 31.4 \\
\hline 20 & 36.9 & 40 & 28.5 \\
\hline Mean & 37.3 & Mean & 32.6 \\
\hline SEM & 1.2 & SEM & $2 \cdot 0$ \\
\hline
\end{tabular}

\section{Discussion}

The easiest definition of a 'true steady state' is to take a period near the end of the study that is used to calculate the plateau enrichment and to do a linear regression of those points against time, computing the slope. Then the slope value for all of the animals is averaged together and a $t$ test is used to determine whether the mean value is significantly different from zero or not. If it is not, then the 'group' is in steady state. In our study we define a 'quasi-steady state' by considering the last $45 \mathrm{~min}$ of each infusion experiment. Thus, the data are 'relative' and much of the error of not being in a true steady state is diminished because of the assumption that all data will be affected. This is probably reasonable for comparing the bicarbonate and acetate results with the triolein because the oleate has to pass through the acetate and bicarbonate pools on its way to be oxidized.

In our experiments with rats, we observed a $13 \%$ difference in percentage oxidation of intravenously supplied triolein labelled with ${ }^{13} \mathrm{C}$ either at position 1 or 8 of the constituent oleic acid chains. This finding means that knowledge of the location of the label within a fatty acid chain is crucial for interpreting the results of isotope tracing of fatty acid oxidation. The observation of a $13 \%$ lower oxidation of the label in position 8 of oleic acid than that in position 1 indicates an incomplete $\beta$-oxidative breakdown of this fatty acid.

These results are in contrast to those of experiments using carboxyl-labelled fatty acids which are based on the assumption of complete breakdown of the fatty acid after initiation of $\beta$-oxidation. This hypothesis is based on studies first carried out by Weinman et al. (1950): they injected tripalmitin, labelled with ${ }^{14} \mathrm{C}$ at the $\mathrm{C}$ atoms 1,6 or 11 of palmitic acid, intravenously into rats. They concluded that the location of the label did not influence significantly the amounts of ${ }^{14} \mathrm{CO}_{2}$ expired. Nevertheless, 1 year later they interpreted the observation of a $20 \%$ difference in the recoveries of $\left[1-{ }^{14} \mathrm{C}\right]-\nu .\left[6-{ }^{14} \mathrm{C}\right]$ tristearin at ${ }^{14} \mathrm{CO}_{2}$ as representing incomplete $\beta$-oxidation (Weinman et al. 1951).

Armstrong et al. (1961) infused tripalmitin ${ }^{14} \mathrm{C}$-labelled at chain- $\mathrm{C}$ atoms 1 or 6 into dogs and found that the amount of label recovered in breath was $31 \%$ lower for $\left[6-{ }^{14} \mathrm{C}\right]$ than for $\left[1-{ }^{14} \mathrm{C}\right]$ tripalmitin, providing additional support for incomplete $\beta$-oxidation. After these early studies, the question of whether or not $\beta$-oxidation was complete received little attention. The almost exclusive use of carboxyl-labelled triacylglycerols or fatty acids for the determination of lipid oxidation has left the question hanging. Our observations suggest that the reported values of fatty acid oxidation (Geyer et al. 1948; Lemer et al. 1949; Eckart et al. 1973; Watkins et al. 1977; Nordenström et al. 1982; Chen, 1984; Paust et al. 1984, 1989; Bender et al. 1985; Brösicke et al. 1985; Park et al. 1986; Silberman, 1986; Wolfram \& Metges, 1988; Adolph et al. 1989; Sulkers et al. 1989; Johnson et al. 1990) would have to be reduced by approximately $13 \%$ (the relative difference between the percentage oxidation of $\left[8-{ }^{13} \mathrm{C}\right]-$ and $\left[1-{ }^{13}\right.$ C $]$ triolein).

The question arises whether or not the fed state influences the rate of lipid oxidation. In theory, feeding 
carbohydrate should cause glucose oxidation to increase markedly. Therefore, the fed state may alter relative oxidation $v$. other fates. Indeed, preliminary studies investigating the percentage recovery of $\left[1-{ }^{14} \mathrm{C}\right]-$ and $\left[2-{ }^{14} \mathrm{C}\right.$ ]acetate as exhaled ${ }^{14} \mathrm{CO}_{2}$ in fasted and TPN-fed rats exhibited higher ${ }^{14} \mathrm{CO}_{2}$ values in the fasted $(72.6$ (SE 2.4) and 55.8 (SE 3.2) respectively) than in the fed state (65.53 (SE 3.8) and 49.2 (SE 3.6) respectively). Nevertheless the $1-{ }^{14} \mathrm{C}: 2-{ }^{14} \mathrm{C}$ ratio remained unaffected (D Scharff, W Bäurle and $P$ Fürst, unpublished results). It is unlikely that once the fatty acid is broken down to the small acetate units, the $\mathrm{C}$ is not oxidized.

Some other aspects, pertinent to the quantification of substrate oxidation by means of ${ }^{13} \mathrm{C}$-labelled compounds, are worthy of discussion. First, not all of the labelled $\mathrm{CO}_{2}$ being released as final product of the oxidative breakdown of a labelled substrate is actually expired. Some of the $\mathrm{CO}_{2}$ is retained in the bicarbonate pools of the body (Wolfe, 1984; Irving et al. 1985). We determined, using a constant infusion of $\mathrm{NaH}^{14} \mathrm{CO}_{3}$, that $90.5 \%$ of the metabolically produced $\mathrm{CO}_{2}$ is excreted, as observed by most other workers using such techniques (Morris \& SimpsonMorgan, 1963; Vazquez et al. 1986; Yagi \& Walser, 1990). This value for bicarbonate retention is within the same range as those assessed by intraperitoneal or intravenous bolus administration of $\left[{ }^{14} \mathrm{C}\right]$ bicarbonate in rats, i.e. from 90 to $98 \%$ (Gould et al. 1949; Greenberg \& Winnick, 1949; Shipley et al. 1959). Two studies reported substantially lower recoveries of $76 \%$ and $50 \%$ (Brooks \& Donovan, 1983; Moldawer et al. 1983). The discrepancy is probably caused by differences in experimental conditions. The animals used in the latter studies were, for example, in the fasting state, which enhances the retention of bicarbonate and the rate of $\mathrm{CO}_{2}$ refixation compared with the fed state (Yang et al. 1983).

Second, the ${ }^{13} \mathrm{C}$-enrichment of expired $\mathrm{CO}_{2}$ must be steady before the isotope administration. Because the natural variation of the ${ }^{13} \mathrm{C}$-enrichment of the diet influences the natural ${ }^{13} \mathrm{C}$-enrichment of the exhaled $\mathrm{CO}_{2}$ (Schoeller et al. 1984), TPN was commenced $2 \mathrm{~d}$ before the stable isotope infusion period. This early changeover from oral feeding to intravenous nutrition was designed to adjust the animals to TPN and to achieve a constant ${ }^{13} \mathrm{C}$ enrichment in breath $\mathrm{CO}_{2}\left({ }^{13} \mathrm{C}\right.$-baseline') for each animal before the isotope administration.

The isotope steady state in expired breath was reached after a mean infusion time of $170 \mathrm{~min}$, which is surprisingly rapid considering the complex metabolism of the infused $\left[{ }^{13} \mathrm{C}\right]$ lipid particles before intracellular oxidation.

The most important aspect is the possible loss of label from fatty acids isotopically labelled at an even-numbered $\mathrm{C}$ atom (like $\left[8^{13} \mathrm{C}\right.$ ]oleic acid) into non-oxidative pathways: $\beta$-oxidation of $\left[8-{ }^{13} \mathrm{C}\right]$ oleic acid generates an acetylCoA molecule labelled with ${ }^{13} \mathrm{C}$ in the methyl group $(\mathrm{C} 2)$, whereas $\beta$-oxidation of $\left[1-{ }^{13} \mathrm{C}\right]$ oleic acid yields acetyl-CoA labelled at its carbonyl $C$ (C 1). When the resulting acetylCoA passes through the citric acid cycle, the $C 1$ is quantitatively cleaved as ${ }^{13} \mathrm{CO}_{2}$, whereas the methyl $\mathrm{C}$ of acetyl-CoA may be directed partly to other metabolic pathways (e.g. formation of phosphoenolpyruvate from the citric acid cycle intermediate oxaloacetate).
Such a different mode of $\mathrm{C}$ handling, as identified by Weinman et al. (1957), may result in underestimation of the oxidation of both $\left[8-{ }^{13} \mathrm{C}\right]$ oleic acid and of the second $\mathrm{C}$ atom of the acetyl-CoA molecule generated from $\left[8-{ }^{13} \mathrm{C}\right]$ oleic acid during $\beta$-oxidation.

For acetyl-CoA labelled in its $\mathrm{C}$ atoms 1 or 2, the loss of isotope in the citric acid cycle was recently demonstrated by Wolfe \& Jahoor (1990) who showed that the recovery of infused $\left[1-{ }^{13} \mathrm{C}\right]$ acetate as expired $\mathrm{CO}_{2}$ was higher than the recovery of $\left[2-{ }^{13} \mathrm{C}\right]-$ or $\left[2-{ }^{14} \mathrm{C}\right]$ acetate.

In the present study the extent of loss of ${ }^{13} \mathrm{C}$ from the second $C$ in acetyl-CoA, which is generated from $\left[8-{ }^{13} \mathrm{C}\right]$ oleic acid, was quantified by comparing the rates of conversion of infused acetate (as precursor to acetyl$\mathrm{CoA}$ ), labelled either at $\mathrm{C} 1$ or 2 , to labelled expiratory $\mathrm{CO}_{2}$. The correction to account for the difference in the recoveries of $\left[2-{ }^{14} \mathrm{C}\right]$ v. $\left[1-{ }^{14} \mathrm{C}\right]$ acetate as breath ${ }^{14} \mathrm{CO}_{2}$ resulted in a true percentage oxidation of $32.6 \%$ for $\left[8-{ }^{13} \mathrm{C}\right]$ triolein. Even after correction for the partial loss of the $\left[8-{ }^{13} \mathrm{C}\right]$ triolein label through the citric acid cycle using [1- $\left.{ }^{14} \mathrm{C}\right]-$ and $\left[2-{ }^{14} \mathrm{C}\right]$ acetate, we still found a significantly lower recovery of the $\left[8-{ }^{13} \mathrm{C}\right]$ triolein relative to the $\left[1-{ }^{13} \mathrm{C}\right]$ triolein. This difference indicates an incomplete breakdown of oleic acid after onset of $\beta$-oxidation which might be caused by partial oxidation and subsequent chain elongation and storage of newly formed fatty acids or triacylglycerol.

We conclude from our experiments that the isotope loss only partly explains the observed differences in ${ }^{13} \mathrm{C}$ recovery of the differently labelled triacylglycerols in breath $\mathrm{CO}_{2}$. This conclusion is in contrast to that of Wolfe \& Jahoor (1990) who stated that the observed isotope loss would completely account for the difference in label recovery in breath between odd- and even-numbered fatty acids.

A small number of studies has been performed up to now using triolein labelled with ${ }^{13} \mathrm{C}$ at the $\mathrm{C} 8$ of the oleic acid chains. Metges et al. (1992) administered [1- $\left.{ }^{13} \mathrm{C}\right]$ - and $\left[8-{ }^{13} \mathrm{C}\right]$ triolein to human volunteers as an enteral bolus. They could not find a significant difference between the mean recoveries of $\left[1-{ }^{13} \mathrm{C}\right]$ and $\left[8-{ }^{13} \mathrm{C}\right]$ triolein in breath $\mathrm{CO}_{2}$. However, when Adolph et al. $(1991 a, b)$ infused the labelled emulsions during TPN in ventilated traumatized patients using the steady-state technique, they found that the mean percentage oxidation of $\left[8{ }^{13} \mathrm{C}\right]$ triolein was $68 \%$ of that of $\left[1-{ }^{13} \mathrm{C}\right]$ triolein, the difference being significant $(P \leq 0.005)$. Neither group determined the bicarbonate retention of their respective study subjects under identical experimental conditions. Instead, they used a standard factor which does not necessarily reflect the retention of bicarbonate during the specific experimental and physiological conditions of their respective studies. Neither did they consider the sequestration of the label derived from $\left[8-{ }^{13} \mathrm{C}\right]$ triolein in the citric acid cycle, leading to erroneous low values of oxidation of $\left[8^{13} \mathrm{C}\right]$ triolein. Applying the correction factor derived from our acetate infusion experiments to the data of Adolph et al. $(1991 a, b)$, the ratio label recovery from $\left[8-{ }^{13} \mathrm{C}\right]$ - : that from $\left[1-{ }^{13} \mathrm{C}\right]$ triolein would be 0.93 , which means that the relative difference between the percentage oxidation of $\left[8-{ }^{13} \mathrm{C}\right]$ triolein and $\left[1-{ }^{13} \mathrm{C}\right]$ triolein would be $7 \%$. 


\section{Conclusions}

(1) Our observation of a higher percentage oxidation of $\left[1-{ }^{13} \mathrm{C}\right]$ triolein compared with $\left[8^{-13} \mathrm{C}\right]$ triolein reflects an incomplete oxidative breakdown of oleic acid after onset of $\beta$-oxidation. Thus, our results do not support the hypothesis of a complete $\beta$-oxidation. Whether alternative metabolic pathways of fatty acids like chain elongation after partial oxidation with subsequent enhanced storage are of physiological or clinical relevance remains to be evaluated.

(2) The use of carboxyl-([1- $\left.\left.{ }^{13} \mathrm{C}\right]-\right)$ labelled triacylglycerols or fatty acids results in the calculation of erroneously high values of fatty acid oxidation. Furthermore, the use of triacylglycerols or fatty acids labelled at an even-numbered $\mathrm{C}$ atom (like $\left[8-{ }^{13} \mathrm{C}\right]$ triolein) results in the calculation of erroneously low values of fatty acid oxidation, if the isotope flux from acetyl-CoA in the course of the citric acid cycle is not considered.

\section{Acknowledgements}

We acknowledge financial support for W.B. from Fresenius AG, Bad Homburg, Germany, and a Research Fellowship from the European Society for Parenteral and Enteral Nutrition (ESPEN).

\section{References}

Adolph M, Eckart J, Metges C, Nesser G \& Wolfram G (1989) Oxidation of long and medium chain triglycerides during total parenteral nutrition of severely injured patients. In Nutrition in Clinical Practice: Proceedings of the 10th Congress ESPEN, Leipzig 1988, pp. 100-110 [W Hartig, G Dietze, R Weiner and P Fürst, editors]. Basel: Karger.

Adolph M, Eckart J, Metges C, Neeser G \& Wolfram G (1991a) Oxidation rates of $\left(1-{ }^{13} \mathrm{C}\right)$ vs. $\left(8^{13} \mathrm{C}\right)$-labeled triolein during TPN of septic ventilated patients. Journal of Parenteral and Enteral Nutrition 15, Suppl., 26S.

Adolph M, Eckart J, Metges C, Neeser G \& Wolfram G (1991b) Recovery of $\left(1-{ }^{13} \mathrm{C}\right)$ vs. $\left(8-{ }^{13} \mathrm{C}\right)$-labeled triolein during TPN of septic ventilated patients. Clinical Nutrition 10, Suppl., 16.

Allsop JR, Wolfe RR \& Burke JF (1978) Tracer priming the bicarbonate pool. Journal of Applied Physiology 45, 137-139.

Armstrong DT, Steele R, Altszuler N, Dunn A, Bishop JS \& De Bodo RC (1961) Regulation of plasma free fatty acid turnover. American Journal of Physiology 201, 9-15.

Bender R, Haller M \& Fürst P (1985) The influence of prior nutritional status on the oxidation rate of ${ }^{14} \mathrm{C}$-labelled MCT or LCT. Clinical Nutrition 4, Suppl., 63.

Brooks GA \& Donovan CM (1983) Effect of endurance training on glucose kinetics during exercise. American Joumal of Physiology 244, E505-E512.

Brösicke H, Paust H, Park W, Knoblach G \& Helge H (1985) Dependence of fat utilization on concomitant carbohydrate administration in parenterally fed low birth weight infants. Clinical Nutrition 4, Suppl., 56.

Chen WJ (1984) Utilization of exogenous fat emulsion (Intralipid) in septic rats. Journal of Parenteral and Enteral Nutrition 8, 14-17.

Eckart J, Tempel G, Kaul A, Witzke G, Schürbrand P \& Schaaf H (1973) Metabolism of radioactive-labeled fat emulsions in the postoperative and posttraumatic period. American Journal of Clinical Nutrition 26, 578-582.
Geyer RP, Chipman J \& Stare FJ (1948) Oxidation in vivo of emulsified radioactive trilaurin administered intravenously. Journal of Biological Chemistry 176, 1469-1470.

Gould RG, Sinex FM, Rosenberg IN, Solomon AK \& Hastings $\mathrm{AB}$ (1949) Journal of Biological Chemistry 177, 295-301.

Greenberg DM \& Winnick T (1949) The transformation in the rat of carboxyl-labeled acetate, methyl-labeled acetate, and labeled bicarbonate into amino acids. Archives of Biochemistry 21, $166-177$.

Irving CS, Lifschitz $\mathrm{CH}$, Wong WW, Boutton TW, Nichols BL \& Klein PD (1985) $\left[{ }^{13} \mathrm{C}\right]$ Bicarbonate kinetics in humans: intra- vs. interindividual variations. Pediatric Research 19, 358-363.

Johnson RJ, Young SK, Cotter R, Lin L \& Rowe B (1990) Medium-chain-triglyceride lipid emulsion: metabolism and tissue distribution. American Journal of Clinical Nutrition $\mathbf{5 2}$, 502-508.

Lerner SR, Chaikoff IL, Entenman C \& Dauben WG (1949) The fate of C-14-labeled palmitic acid administered intravenously as a tripalmitin emulsion. Proceedings of the Society for Experimental Biology and Medicine 70, 384-387.

Metges CC, Kempe K \& Wolfram G (1992) Relative ${ }^{13} \mathrm{CO}_{2}$ recovery rates of orally administered $\left[1-{ }^{13} \mathrm{C}\right]$ and $\left[8-{ }^{13} \mathrm{C}\right]$ triolein and ${ }^{13} \mathrm{C}$ enrichments of fatty acids in selected serum lipids in humans. Clinical Nutrition 11, Suppl., 20.

Moldawer LL, Kawamura I, Bistrian BR \& Blackburn GL (1983) The contribution of phenylalanine to tyrosine metabolism in vivo: studies in the post-absorptive and phenylalanine-loaded rat. Biochemical Journal 210, 811-817.

Morris B \& Simpson-Morgan MW (1963) The excretion of ${ }^{14} \mathrm{CO}_{2}$ during the continuous intravenous infusion of $\mathrm{NaH}^{14} \mathrm{CO}_{3}$ in unanaesthetized rats. Journal of Physiology 169, 713-728.

Nordenström J, Carpentier YA, Askanazi J, Robin AP, Elwyn DH, Hensle TW \& Kinney JM (1982) Metabolic utilization of intravenous fat emulsion during total parenteral nutrition. Annals of Surgery 196, 221-231.

Park W, Paust H, Brösicke H, Knoblach G \& Helge H (1986) Impaired fat utilization in parenterally fed low-birth-weight infants suffering from sepsis. Journal of Parenteral and Enteral Nutrition 10, 627-630.

Paust H, Park W, Rating D \& Helge H (1984) Measurement of fatty acid oxidation in premature newborn infants with the ${ }^{13} \mathrm{C}$ triolein breath test. Clinical Nutrition 3, 89-92.

Paust H, Park W, Knoblach G, Keles T \& Scigalla P (1989) Measurement of substrate utilization by ${ }^{13} \mathrm{C}$ tracer infusion technique. In Nutrition in Clinical Practice: Proceedings of the 10th Congress ESPEN, Leipzig 1988, pp. 111-128 [W Hartig, G Dietze, R Weiner and P Fürst, editors]. Basel: Karger.

Schoeller DA, Brown C, Nakamura K, Nagakawa A, Mazzeo RS, Brooks GA \& Budinger TF (1984) Influence of metabolic fuel on the ${ }^{13} \mathrm{C} /{ }^{12} \mathrm{C}$ ratio of breath $\mathrm{CO}_{2}$. Biomedical Mass Spectrometry 11, 557-561.

Schoeller DA, Klein PD, Watkins JB, Heim T \& MacLean WC Jr (1980) ${ }^{13} \mathrm{C}$ abundances of nutrients and the effect of variations in ${ }^{13} \mathrm{C}$ isotopic abundance of test meals formulated for ${ }^{13} \mathrm{CO}_{2}$ breath test. American Journal of Clinical Nutrition 33, 23752385.

Scrimgeour CM \& Rennie MJ (1988) Automated measurement of the concentration and ${ }^{13} \mathrm{C}$ enrichment of carbon dioxide in breath and blood samples using the Finnigan MAT breath gas analysis system. Biomedical and Environmental Mass Spectrometry 15, 365-367.

Shipley RA, Baker N, Incefy GE \& Clark RE (1959) ${ }^{14} \mathrm{C}$ Studies in carbohydrate metabolism. IV. Characteristics of bicarbonate pool system in the rat. American Journal of Physiology 197, $41-46$. 
Silberman H (1986) Total parenteral nutrition by peripheral vein: current status of fat emulsions. Nutrition International 2, 145149.

Statistical Analysis Systems (1988) SAS/STAT ${ }^{\mathrm{TM}} U_{s e r}$ 's Guide, Release 6.03 Edition. Cary, NC: SAS Institute Inc.

Sulkers EJ, Lafeber HN \& Sauer PJJ (1989) Quantitation of oxidation of medium-chain triglycerides in preterm infants. Pediatric Research 26, 294-297.

Thompson GN, Pacy PJ, Ford GC \& Halliday D (1989) Practical considerations in the use of stable isotope labelled compounds as tracers in clinical studies. Biomedical and Environmental Mass Spectrometry 18, 321-327.

Vazquez JA, Paul HS \& Adibi SA (1986) Relation between plasma and tissue parameters of leucine metabolism in fed and starved rats. American Journal of Physiology 250, E615E621.

Watkins JB, Schoeller DA, Klein PD, Ott DG, Newcomer AD \& Hofman AF (1977) ${ }^{13}$ C-Trioctanoin: a nonradioactive breath test to detect fat malabsorption. Journal of Laboratory and Clinical Medicine 90, 422-430.

Weinman EO, Chaikoff IL, Dauben WG, Gee M \& Entenman C (1950) Relative rates of conversion of the various carbon atoms of palmitic acid to carbon dioxide by the intact rat. Journal of Biological Chemistry 184, 735-744.

Weinman EO, Chaikoff IL, Stevens BP \& Dauben WG (1951) Conversion of first and sixth carbons of stearic acid to carbon dioxide by rats. Journal of Biological Chemistry 191, 523529.

Weinmann EO, Strisower EH \& Chaikoff IL (1957). Conversion of fatty acids to carbohydrate: application of isotopes to this problem and role of the Krebs cycle as a synthetic pathway. Physiological Reviews 37, 252-272.

Wolfe RR (1984) Tracers in metabolic research: radioisotope and stable isotope. In Mass Spectrometry Methods, pp. 55-59. New York: Alan R. Liss, Inc.

Wolfe RR \& Jahoor F (1990) Recovery of labeled $\mathrm{CO}_{2}$ during the infusion of C-1 v. C-2-labeled acetate: implications for tracer studies of substrate oxidation. American Journal of Clinical Nutrition 51, 248-252.

Wolfram G \& Metges C (1988) Fatty acid oxidation following enteral or parenteral application of ${ }^{13} \mathrm{C}$-labeled medium chain and long chain triglycerides. In Klinische Ernährung 34: Use of Stable Isotopes in Clinical Research and Practice, pp. 89-92 [H Paust, W Park, H Helge and P Scigalla, editors]. München: W. Zuckschwerdt Verlag.

Yagi M \& Walser M (1990) Estimation of whole body protein synthesis from oxidation of infused $\left[1{ }^{14} \mathrm{C}\right]$-leucine. American Joumal of Physiology 258, E151-E157.

Yang RD, Irving CS, Wong WW, Hoffer JH, Young VR \& Klein PD (1983) The effect of diet and meal ingestion on whole body ${ }^{13} \mathrm{C}$-bicarbonate kinetics in young men. Federation Proceedings 42, 825 . 